\title{
Statyba
}

\section{DETERMINATION OF UNIT CHARACTERISTICS OF CONCRETE LINEAR CREEP}

\section{R. Balevičius \& E. Dulinskas}

To cite this article: R. Balevičius \& E. Dulinskas (2000) DETERMINATION OF UNIT CHARACTERISTICS OF CONCRETE LINEAR CREEP, Statyba, 6:2, 87-96, DOI:

10.1080/13921525.2000.10531571

To link to this article: https://doi.org/10.1080/13921525.2000.10531571

曲 Published online: 26 Jul 2012.

Submit your article to this journal

III Article views: 57 


\section{BETONO TIESINIO VALKŠNUMO VIENETINIŲ RODIKLIU NUSTATYMAS}

\author{
R. Balevičius, E. Dulinskas \\ Vilniaus Gedimino technikos universitetas
}

\section{Ivadas}

Skaičiuojant gelžbetonines konstrukcijas svarbu ivertinti ilgalaikes betono netampriąsias deformacijas bei fizinių ir mechaninių rodiklių kitimą. Daugelio šaliu normose, tokiose kaip ENV 1992-1-1 (Euronormos) [1], ACI 209-92 (JAV), AS 3600-1988 (Australija), DIN 4227 (Vokietija) ir kitose, valkšnumo deformaciju ir fizinių bei mechaninių rodiklių kitimas per laiką yra reglamentuojamas. Lietuvoje galiojančios normos SNirT (rus. СНиП 2.03.01-84*) [2] tokiu rodiklių tiesiogiai neaprašo.

Lietuvoje galiojančiose normose SNirT [2] ilgalaikių procesu skaičiavimai nesusiję su vienetinių valkšnumo rodiklių (valkšnumo mato, valkšnumo charakteristikos) bei valkšnumo deformaciju reglamentavimu. Su šiomis charakteristikomis susiję tokie integraliniai rodikliai, kaip armatūros išankstinio itempimo nuostoliai dèl betono valkšnumo, skaičiuojami pagal empirines formules, kurios gautos eksperimentais patikrinus atskiru elementų itempimų ir deformaciju būvi.

Tiriant vienetinius tiesinio betono valkšnumo rodiklius, atlikta daug darbu. Darbe [3] siūloma nustatant ,jaunų“ ir ,senu“ betony vienetinius rodiklius taikyti skirtingas priklausomybes, rekomendacijose [4], kaip nurodo ju autoriai, pateikti rodikliai skirti tik projektavimui, monografijoje [5] pateiktos priklausomybès gerai aprašo ,jauno“ betono valkšnuma, normose [6] - reglamentuojamos tik ribinès valkšnumo rodiklių reikšmès. Pagal Euronormas [1] nustatyti rodikliai priklauso nuo pagrindinių valkšnumo deformacijas lemiančių faktoriu, tačiau neaiškus ju saryšis su taikomų Lietuvoje normų [2] nuostatomis.

Todèl šiame darbe buvo pasiūlytos ivvairių sunkiojo betono gniuždymo klasiu vienetiniu valkšnumo rodikliu priklausomybes, aprašančios didelę ilgalaikiu deformaciju sriti ir jvertinančios pagrindinių faktorių itaką betono valkšnumui. Pasiūlytos priklausomybés tenkina ir normų [2] nuostatu sriti.

\section{Betono valkšnumo vienetinių rodiklių nustatymas}

Pradžioje panagrinėsime normu [2] nuostatas apimančia valkšnumo rodiklių sriț. Galiojancios normos [2] priklausomai nuo gelžbetonio gamybos būdo reglamentuoja greitai pasireiškiančio valkšnumo ir po apspaudimo vykstančius armatūros išankstinio itempimo nuostolius dèl betono valkšnumo. Normy [2] nuostolių skaiciavimo metodika neivertina armatūros ittempimų atstojamosios kitimo dèl betono valkšnumo. Be to, nuostoliai tiesiogiai nepriklauso nuo betono klasès, armavimo procento, elemento masyvumo bei aplinkos drègmès faktoriu. Pastarieji lemia betono valkšnuma ir reglamentuojami Euronormose (toliau EC-2) [1], tiltu ir pralaidu projektavimo normose [6] bei NIIŽB rekomendacijose [4].

Armatüros išankstinio įtempimo nuostoliu dèl betono valkšnumo skaičiavimas pagal SNirT [2] reglamentuojamas B15-B60 sunkiojo betono klasès konstrukcijoms. Betono kubelių norminis stiprumas išankstinio apgniuždymo metu $R_{b p}$ pagal [2] reikalavimus turi būti ne mažesnis kaip pusė betono gniuždymo klasès ir ne mažesnis kaip $11 \mathrm{MPa}$. Jeigu betono apspaudimas atliekamas po 28 paru nuo jo kietėjimo pradžios, tuomet betono kubelių stiprumas $R_{b p}$ yra lygus betono klasei $B$. Atsižvelgiant $\mathfrak{i}$ normu [2] reikalavimus, galima nustatyti betono tiesinès valkšnumo srities ribini apspaudimo intensyvuma, kai ilgalaikès betono valkšnumo deformacijos proporcingos tik itempimams.

Betono apspaudimo intensyvumas $\eta_{6}$ išankstinio apgniuždymo metu ir ilgalaikis apspaudimo intensyvumas $\eta_{9}$ pagal normas [2] turi tenkinti sąlygas:

$$
\begin{gathered}
\eta_{6}=\frac{\sigma_{b p}}{R_{b p}}=0,25+0,025 R_{b p} \leq 0,8 . \\
\eta_{9}=\frac{\sigma_{b p}}{R_{b p}} \leq 0,75 .
\end{gathered}
$$


Ryšys tarp betono apspaudimo intensyvumų $\eta_{6}$ ir $\eta_{9}$ gali būti išreiškiamas taip:

$$
\eta_{9}=\eta_{6}\left(1-\frac{\sigma_{6}}{\sigma_{s p 0}}\right)
$$

$\sigma_{6}-$ armatūros išankstinio ịtempimo nuostoliai dèl greitai pasireiškiančio betono valkšnumo pagal normas [2]; $\sigma_{s p 0}$ - armatūros išankstinis itempimas.

Pagal (1-2) priklausomybes apskaičiuotos betono tiesinès valkšnumo srities ribinès intensyvumo reikšmès pateikiamos 1 lentelèje.

1 lentelè. Tiesinès valkšnumo srities ribinès betono apspaudimo intensyvumo reikšmès

Table 1. Limit intensity values of linear concrete creep area

\begin{tabular}{|c|c|c|c|}
\hline \multirow{2}{*}{$\begin{array}{c}\text { Apspaudimo } \\
\text { intensyvumas }\end{array}$} & \multicolumn{3}{|c|}{ Betono klase } \\
\cline { 2 - 4 } & B15 & B20 & B25 $\div$ B60 \\
\hline$\eta_{6}$ & 0,63 & 0,75 & 0,8 \\
\hline$\eta_{9}$ & \multicolumn{3}{|c|}{0,75} \\
\hline
\end{tabular}

Pagal normas [2], esant normaliam aplinkos drègnumui, tiesinès valkšnumo srities armatūros išankstinio itempimo nuostoliai dèl greitai pasireiškiančio ir ilgalaikio betono valkšnumo apskaičiuojami:

$$
\begin{gathered}
\sigma_{6}=40 \frac{\sigma_{b p}}{R_{b p}}=40 \eta_{6}, \\
\sigma_{9}(t)=\alpha 150 \varphi_{l}(t) \frac{\sigma_{b p}}{R_{b p}}=\alpha 150 \eta_{9} \frac{4 t}{100+3 t},
\end{gathered}
$$

$\alpha$ - koeficientas, kurio reikšmès priklauso nuo betono kietèjimo salygu ( $\alpha=1,0$, jeigu betonas kietèja natūraliomis sąlygomis); $\varphi_{l}(t)$ - koeficientas, kuriuo ivertinamas nuostolių kitimas per laiką; $t$ - laikotarpis nuo konstrukcijos apgniuždymo momento $t_{0}$ iki stebejjimo momento $t=t-t_{0}$.

Kai armatūra ir betonas dirba kartu, betono plastinès deformacijos $\varepsilon_{b, p l 6}\left(t_{0}\right)$ ir $\varepsilon_{b, p l 9}\left(t, t_{0}\right)$, atsiradusios dèl atitinkamai greit pasireiškiančio ir ilgalaikio betono valkšnumo, apskaičiuojamos taip:

$$
\begin{gathered}
\varepsilon_{b, p l 6}\left(t_{0}\right)=\varepsilon_{s p 6}\left(t_{0}\right)=\frac{\sigma_{6}}{E_{s p}}, \\
\varepsilon_{b, p l 9}\left(t, t_{0}\right)=\varepsilon_{s p 9}\left(t, t_{0}\right)=\frac{\sigma_{9}(t)}{E_{s p}},
\end{gathered}
$$

$E_{s p}$ - îtemptosios armatüros tamprumo modulis.

Bendrosios netampriosios betono deformacijos laiko momentu $t$ :

$$
\varepsilon_{b, p l}\left(t, t_{0}\right)=\frac{\sigma_{6}}{E_{s p}}+\frac{\sigma_{9}(t)}{E_{s p}}
$$

Esant betono įtempimų $\sigma_{b}(t)$ pokyčiui tiesinio valkšnumo srityje, jo deformacijos laikotarpiu $t-t_{0}$ nustatomos taikant žinomas valkšnumo teorijos priklausomybes $[3,5$, 7-9]:

$$
\begin{gathered}
\varepsilon_{b}(t)=\sigma_{b}\left(t_{0}\right) \delta\left(t, t_{0}\right)+\int_{t_{0}}^{t} \frac{\partial \sigma_{b}(\tau)}{\partial \tau} \delta(t, \tau) \partial \tau=\frac{\sigma_{b}(t)}{E_{b}(t)}- \\
-\int_{t_{0}}^{t} \sigma_{b}(\tau) \frac{\partial \delta(t, \tau)}{\partial \tau} \partial \tau=\frac{\sigma_{b}(t)}{E_{b}(t)}+\sigma_{\xi}\left(t, t_{0}\right) C^{*}\left(t, t_{0}\right)= \\
=\varepsilon_{b, e l}(t)+\varepsilon_{b, p l}\left(t, t_{0}\right),
\end{gathered}
$$

čia $\sigma_{b}\left(t_{0}\right)$ - per laiką $t_{0}$ apkrauto betono itempimai armatūros svorio centro lygyje; $\delta\left(t, t_{0}\right)$ ir $\delta(t, \tau)$ - betono vienetinès bendrosios deformacijos laikotarpiu $t-t_{0}$ ir $t-\tau$, $E_{b}(t)$ - betono tamprumo modulis nagrinejjamu laiko momentu $t ; \sigma_{\xi}\left(t, t_{0}\right)$ - vidutiniai ekvivalentiniai betono itempimai armatūros svorio centro lygyje per laiko intervalą $t-t_{0}$, sukeliantys tokias pačias betono valkšnumo deformacijas, kaip ir kintami betono itempimai $\sigma_{b}\left(t_{0}\right) \leq \sigma_{b}(\tau) \leq \sigma_{b}(t) ; C^{*}\left(t, t_{0}\right)$ - betono grynasis valkšnumo matas $[4,5]$.

Ivertinus (9) priklausomybèje esančias betono plastines deformacijas $\varepsilon_{b, p l}\left(t, t_{0}\right)$, apskaičiuojamas grynojo valkšnumo matas:

$$
C^{*}\left(t, t_{0}\right)=\frac{\varepsilon_{b, p l}\left(t, t_{0}\right)}{\sigma \xi\left(t, t_{0}\right)}=C\left(t, t_{0}\right)+\frac{1}{E_{b}\left(t_{0}\right)}-\frac{1}{E_{b}(t)} \text {. }
$$

Skaičiuojant armatūros išankstinio ịtempimo nuostolius [4] dèl betono valkšnumo, taikomas ne betono valkšnumo matas $C\left(t, t_{0}\right)$, o grynojo valkšnumo matas, kuris ivertina betono tampriuju deformacijų mažejimą dèl betono tamprumo modulio didejimo per laiką $t$. Ivertinus (8) ir (10) priklausomybes, grynojo valkšnumo matas apskaičiuojamas taip:

$$
C^{*}\left(t, t_{0}\right)=\frac{\sigma_{6}+\sigma_{9}(t)}{\sigma_{\xi}\left(t, t_{0}\right) E_{s p}}
$$

Centriškai armuoto elemento betono ittempimai išankstinio apgniuždymo metu apskaičiuojami taip: 


$$
\sigma_{b}\left(t_{0}\right)=\sigma_{b p}=R_{b p} \eta\left(t_{0}\right)=\sigma_{s p 0}\left(\frac{\mu}{1+\alpha\left(t_{0}\right) \mu}\right) .
$$

Armatūros išankstiniai ịtempimai, îvertinus (12) priklausomybę, nustatomi pagal formulę:

$$
\sigma_{s p 0}=\frac{1}{k_{\alpha \mu}\left(t_{0}\right)} R_{b p} \eta\left(t_{0}\right)
$$

čia

$$
k_{\alpha \mu}\left(t_{0}\right)=\frac{\mu}{1+\alpha\left(t_{0}\right) \mu},
$$

kur

$$
\alpha\left(t_{0}\right)=\frac{E_{s p}}{E_{b}\left(t_{0}\right)},
$$

$k_{\alpha \mu}\left(t_{0}\right)$ - koeficientas, kurio reikšmé priklauso nuo betono tamprumo modulio apgniuždymo momentu $t_{0}$ ir armatūros kiekio.

Betono itempimai $\sigma_{b}(t)$ priklauso nuo armatūros išankstinio itempimo nuostolių dèl betono valkšnumo kitimo per laiką $t$. Ivertinus (4-5), (9), (12), (14-15) priklausomybes, šie ittempimai laiko momentu $t$ apskaičiuojami taip:

$$
\begin{aligned}
& \sigma_{b}(t)=\eta(t) B_{p}(t)=\frac{\mu}{1+\alpha(t) \mu}\left(\sigma_{s p 0}-\sigma_{\xi}\left(t, t_{0}\right) \times\right. \\
& \left.\times C^{*}\left(t, t_{0}\right) E_{s p}\right)=k_{\alpha \mu}(t)\left(\sigma_{s p 0}-\sigma_{6}-\sigma_{9}(t)\right)= \\
& =k_{\alpha \mu}(t)\left(\sigma_{s p 0}-40 \eta_{6}-\varphi_{l}(t) 150 \eta_{9}\right) .
\end{aligned}
$$

Reikia pažymèti, kad betono gniuždymo klasè elemento apspaudimo metu $R_{b p}$, betono tamprumo modulis $E_{b}(t)$ ir koeficientas $k_{\alpha \mu}\left(t_{0}\right)$ laiko atžvilgiu nèra pastovūs dydžiai. Pagal normų [2] nuostatas jų kitimas nevertinamas, todèl $k_{\alpha \mu}(t)$ apskaičiuojamas taip:

$$
k_{\alpha \mu}(t)=k_{\alpha \mu}=\frac{\mu}{1+\alpha\left(t_{28}\right) \mu} .
$$

Ivertinus (3), (13-17) priklausomybes, vidutiniai ekvivalentiniai betono itempimai $\sigma_{\xi}\left(t, t_{0}\right)$ per laiko intervalą $t-t_{0}$ apskaičiuojami taip:

$$
\begin{aligned}
& \sigma_{\xi}\left(t, t_{0}\right)=\frac{\int_{0}^{t-t_{0}} \sigma_{b}(t)}{t-t_{0}}=\frac{\eta_{6}}{t-t_{0}} \int_{0}^{t-t_{0}}\left[R_{b p} \frac{1}{k_{\alpha \mu}}-40-\right. \\
& \left.-\left(\frac{4\left(t-t_{0}\right)}{3\left(t-t_{0}\right)+100}\right)\left(1-\frac{40 k_{\alpha \mu}}{R_{b p}}\right) 150\right] k_{\alpha \mu} d\left(t-t_{0}\right) .
\end{aligned}
$$

Išsprendus (18) priklausomybès integralą kintamojo $0 \leq t-t_{0} \leq 100$ atžvilgiu ir ivertinus (11) išraiška, gaunama grynojo valkšnumo mato priklausomybè, kuri tenkina normu SNirT [2] armatūros išankstinio itempimo nuostolių dèl betono valkšnumo skaičiavimo nuostatas:

$$
\begin{gathered}
C^{*}\left(t, t_{0}\right)=\frac{120\left(600 k_{\alpha \mu}-19 R_{b p}\right)}{E_{s p}} \times \\
\left.\times \frac{1}{\left(-12 R_{b p}^{2}+1771 k_{\alpha \mu} R_{b p}+44360 k_{\alpha \mu}^{2}-3600 k_{\alpha \mu}\right.}\right)
\end{gathered}
$$

Kaip rodo (19) priklausomybè, norminis [2] grynojo valkšnumo matas priklauso nuo armatūros tamprumo modulio, betono gniuždymo klasès apgniuždymo metu ir koeficiento $k_{\alpha \mu}$. Kai išankstinis apgniuždymas atliekamas esant $t_{0}=28$, tuomet $R_{b p}=B$. Išanalizavus normų [2] itemptojo gelžbetonio konstrukcijoms taikomus B20 B60 betono klasiu ir tamprumo moduliu kitimo intervalu bei konstrukcijų armavimui reglamentuojamu $0,5 \%-3 \%$ armavimo ribu itaka grynojo valkšnumo matui (19), koeficientas $k_{\alpha \mu}=0,009327$. Armatūros tamprumo modulis itemptojo gelžbetonio konstrukcijoms kinta nežymiai, todèl pagal normų [2] nuostatas $E_{s p} \approx 200000 \mathrm{MPa}$. Ivertinus nustatytus dydžius, grynojo valkšnumo matas (19) apskaičiuojamas pagal formulę:

$$
C^{*}\left(t, t_{0}\right)=C_{n}^{*}(128,28)=\frac{2280 B-671,54}{\left(2,40 B^{2}-3,30 B+5,94\right) \cdot 10^{6}} .
$$

1 pav. pateikiamas grynojo valkšnumo mato, apskaičiuoto pagal (20) priklausomybę, palyginimas su normų EC-2 [1] grynojo valkšnumo matu, esant santykinei aplinkos drègmei $\mathrm{RH}=70 \%$ ir $h=50 \mathrm{~mm}, h=600 \mathrm{~mm}$ bei sąlyginiams skerspjūvio matmenims.

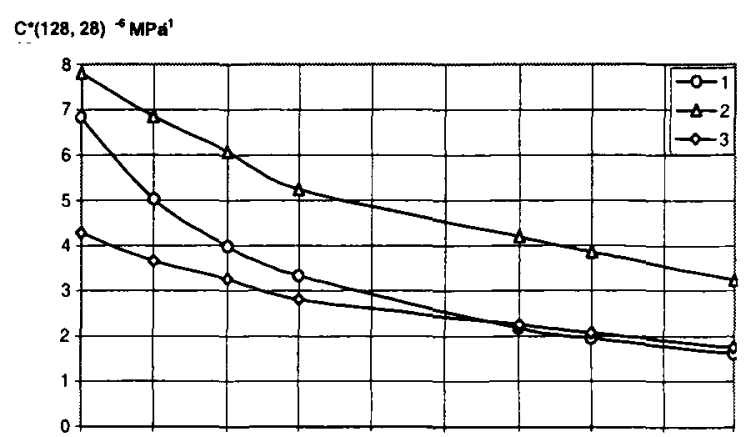

1 pav. Grynojo valkšnumo matų $C^{*}(128,28)$ palyginimas: 1 - apskaičiuotas pagal (20) priklausomybę, 2 apskaičiuotas pagal normų EC-2 [1] metodika, kai sąlyginis matmuo $h=50 \mathrm{~mm}, 3$ - tas pats, kai salyginis matmuo $h=600 \mathrm{~mm}$

Fig 1. Comparison of pure specific creep $C^{*}(128,28)$ : 1 calculated by relationship (20), 2 - calculated by code EC-2 [1] method when conventional dimension $h=50 \mathrm{~mm}, 3$ - the same when $h=600 \mathrm{~mm}$ 
Kaip rodo 1 pav. grafikas, grynojo valkšnumo matas, apskaičiuotas pagal (20) priklausomybę, pakankamai sutampa tik su masyvių konstrukcijų valkšnumo matu (kai $h=600 \mathrm{~mm}$ ), apskaičiuotu pagal normas [1]. Todèl grynojo valkšnumo mata, apskaičiuota pagal normų [2] nuostatas, tikslinga taikyti tik masyvioms arba izoliuotoms nuo drègmès praradimo konstrukcijoms. Mažesnio masyvumo konstrukcijoms mastelio faktoriaus itaką siūloma ivertinti analogišku normu [6] koeficientu $\xi_{3}$. I Ivertinant santykinès aplinkos drègmès faktoriaus itaką taip pat taikytinas normy [6] koeficientas $\xi_{4}$. Tuomet grynojo valkšnumo matas apskaičiuojamas taip:

$$
\begin{gathered}
C_{n}^{*}(128,28)=\left(\frac{2280 B-671,54}{\left(2,40 B^{2}-3,30 B+5,94\right) \cdot 10^{6}}\right) \xi_{3}^{*} \xi_{4} . \\
\xi_{3}^{*}=\xi_{3} / 0.64,
\end{gathered}
$$

$\operatorname{kur} \xi_{3}^{*}$ - koeficientas, kuriuo iqvertinamas elemento masyvumas; $\xi_{3}$ - koeficientas, kuriuo ivertinama elemento mastelio faktoriaus itaka valkšnumo deformacijoms priklausomai nuo sqlyginès skerspjūvio charakteristikos pagal [6]; $\xi_{4}-$ koeficientas, kuriuo ivertinama aplinkos santykinès drégmès itaka valkšnumo deformacijoms pagal [6].

Grynojo valkšnumo charakteristika apskaičiuojama taip:

$$
\varphi_{n}^{*}(128,28)=\frac{(2280 B-671,54) \xi_{3}^{*} \xi_{4} E_{b}}{\left(2,40 B^{2}-3,30 B+5,94\right) \cdot 10^{6}},
$$

$E_{b}$ - pradinis betono tamprumo modulis, praejus 28 paroms nuo betono kietèjimo pradžios pagal [2].

Ivertinus elemento masyvumo ir drègmès itakos koeficientus pagal (21) formulę, apskaičiuotas grynojo valkšnumo matas buvo palygintas su rekomendaciju [4] reglamentuotu grynojo valkšnumo matu priklausomai nuo mišinio slankumo (2 pav.). Pagal [4] nuostatas grynojo valkšnumo mato reikšmès apskaičiuotos, kai sąlyginè skerspjūvio charakteristika $r=3,75 \mathrm{~cm}(15 \times 15 \mathrm{~cm})$.

2 pav. pateiktas grafikas rodo, kad, ivertinus konstrukcijos mastelio bei drègmès faktoriu itakos koeficientus, apskaičiuotas pagal (21) formulę valkšnumo matas neišeina iš valkšnumo mato, nustatyto pagal NIIŽB-o rekomendaciju [4] metodiką kitimo ribu priklausomai nuo betono mišinio slankumo.

Taikant siūlomą metodiką taip pat galima apskaičiuoti betono valkšnumo vienetinius rodiklius remiantis įtemptojo gelžbetonio elementų eksperimentinių tyrimų rezultatais [10]. Tuo šis metodas pranašesnis už NIIŽB-o rekomendacijų [4] metodiką, kuri skirta tik projektavimui.

$\mathrm{C}(12 \mathrm{Q}, 28) 10^{6} \mathrm{MPa}^{-1}$

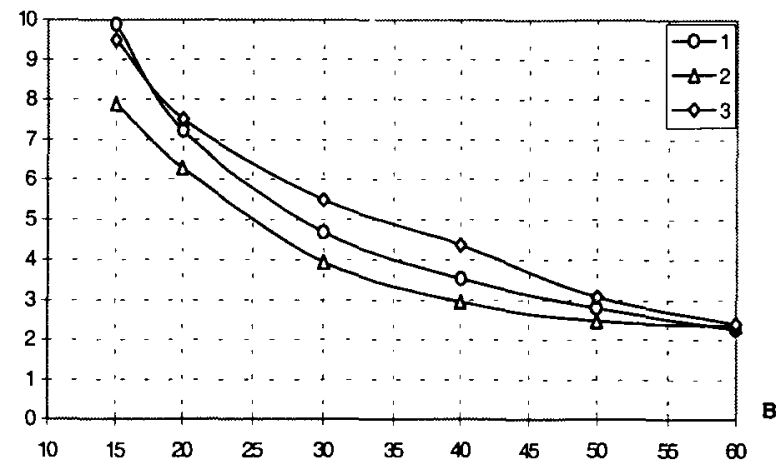

2 pav. Grynojo valkšnumo matų palyginimas: 1 - apskaičiuotas pagal (21) priklausomybę, 2 - nustatytas pagal NIIŽB-o rekomendaciju [4] metodika esant minimaliam mišinio slankumui, 3 - tas pats, kai mišinio slankumas yra maksimalus

Fig 2. Comparison of pure specific creep values: 1 - calculated by relationship (21), 2 - calculated by NIIZHB recommended method [4] at the minimum slump, 3 - the same when the slump is maximum

\section{Vienetinį̨ tiesinio valkšnumo rodiklį̣ matematinis aprašymas}

Betono valkšnumo vienetinems deformacijoms aprašyti yra pasiūlyta nemaža matematinių modeliụ, tenkinancių ivairias valkšnumo teorijas $[3,5,7,11-14]$. Atlikus ivairių priklausomybių analizę, grynojo valkšnumo matui (21) aprašyti pritaikytas S. Aleksandrovskio pasiūlytas tampriai valkšnaus kūno skaičiavimo modelis [5], kuri mes modifikavome visai tiesinio valkšnumo sričiai:

$$
\begin{gathered}
C^{*}\left(t, t_{0}\right)=\frac{1}{E\left(t_{0}\right)}-\frac{1}{E(t)}+\psi\left(t_{0}\right)- \\
-\psi(t)\left[\frac{e^{0,02 t_{0}}-0,3}{e^{0,02 t}-0,3}\right]+\Delta\left(t_{0}\right) e^{-3\left(t-t_{0}\right)} . \\
\Delta\left(t_{0}\right)=\left(11,2+34 e^{-0,125 t_{0}}\right) 10^{-6} \\
\psi\left(t_{0}\right)=\varphi\left(t_{0}\right)-\Delta\left(t_{0}\right) \\
\varphi\left(t_{0}\right)=\left(24,5+10 e^{-0,023 t_{0}}+\right. \\
\left.+43,2 e^{-0,1275 t_{0}}-36 e^{-0,35 t_{0}}\right) 10^{-6} \\
E_{b}(t)=E_{b}(\infty)\left(1-0.575 e^{-0,072 t}\right),
\end{gathered}
$$

$E_{b}\left(t_{0}\right)$ - betono pradinis tamprumo modulis apkrovimo metu $t_{0} ; E_{b}(t)$ - betono pradinis tamprumo modulis stebé- 
jimo momentu $t ; E_{b}(\infty)$ - ,seno" betono tamprumo modulis pagal [3]; $\Delta\left(t_{0}\right)$ - greitai pasireiškiančio valkšnumo deformaciju dalis, $\mathrm{MPa}^{-1}$.

Priklausomybès (24) modifikavimas normų [2] nuostatų apibréžtai sričiai išplečia jos taikymo diapazoną „seniems“" ir ,jauniems“ betonams. Koeficientas $k_{6}$, ivertinantis betono klasę ir greitai pasireiškianti betono valkšnumą, gali būti išreikštas santykiniu dydžiu:

$$
k_{6}=\frac{\varepsilon_{b, p l 6}\left(t_{0}\right)}{\sigma_{\xi}\left(t, t_{0}\right) \Delta\left(t_{0}\right)}
$$

Atsižvelgiant $\mathfrak{i}(6)$ ir (18) išraiškas bei 2 skirsnyje nustatytus dydžius $\left(E_{s p}=200000 \mathrm{MPa}, k_{\alpha \mu} \approx 0,009327\right.$, $t_{0}=28$ paros, $R_{b p}=B, t=128$ paros, $t-t_{0}=128-28=100$ paru), koeficientas $k_{6}$ apskaičiuojamas pagal formulę:

$$
k_{6}=\frac{480 B}{29 B^{2}-40 B+7,3} \text {. }
$$

Ivertinantis betono klasę ir ilgalaikes betono valkšnumo deformacijas koeficientas

$$
k_{9}=\frac{1}{C_{a, 9}^{*}\left(t, t_{0}\right)} \frac{\varepsilon_{b, p l 9}\left(t, t_{0}\right)}{\sigma_{\xi}\left(t, t_{0}\right)} .
$$

Čia $C_{a, 9}^{*}\left(t, t_{0}\right)$ - betono vienetinių valkšnumo deformacijų (24) ilgalaikè dalis:

$$
\begin{aligned}
& C_{a, 9}^{*}\left(t, t_{0}\right)=\frac{1}{E_{b}\left(t_{0}\right)}-\frac{1}{E_{b}(t)}+\psi\left(t_{0}\right)- \\
& -\psi(t)\left[\frac{e^{0,02 t_{0}}-0,3}{e^{0,02 t}-0,3}\right]-\Delta\left(t_{0}\right) e^{-3\left(t-t_{0}\right)} .
\end{aligned}
$$

Kai $t_{0}<28$, koeficientas $k_{9}$ apskaičiuojamas atsižvelgiant $\mathfrak{i}$ apkrovimo laiką $t_{0}$ :

$$
k_{9}=\frac{(2,7 B-1)\left(-0,27 t_{0}^{3}+14,51 t_{0}^{2}-225,5 t_{0}+1661,9\right)}{\left(2,4 B^{2}-3,30 B+5,94\right)\left(\frac{0,083}{E_{b}(\infty)}+1,72 \cdot 10^{-5}\right) \cdot 10^{6}} .
$$

Kai $t_{0} \geq 28$, koeficientas $k_{9}$ apskaičiuojamas taip:

$$
k_{9}=\frac{1800 B-671,54}{\left(2,4 B^{2}-3,30 B+5,94\left(\frac{0,083}{E_{b}(\infty)}+1,72 \cdot 10^{-5}\right) \cdot 10^{6}\right.} .
$$

Taikant (30-34) priklausomybes koeficientams $k_{6}$ ir $k_{9}$ skaičiuoti, gauta fenomenologinè valkšnumo teorijos grynojo valkšnumo mato išraiška, ivvertinanti pagrindinius faktorius: betono klasę, apkrovimo ir stebejimo laikus, mastelị ir aplinkos drègmę:

$$
\left\{\begin{array}{l}
C^{*}\left(t, t_{0}\right)=\left[C_{a, 9}^{*}\left(t, t_{0}\right) k_{9}+\Delta\left(t_{0}\right) k_{6}\right]_{3}^{*} \xi_{4}, \\
\text { esant } \mathrm{t}-\mathrm{t}_{0} \leq 100 \\
C^{*}\left(t, t_{0}\right)=C^{*}\left(z+t_{0}, t_{0}\right) \Omega(t), \mathrm{t}-\mathrm{t}_{0}>100 \\
\mathrm{z}=\mathrm{t}-\mathrm{t}_{0}=100
\end{array}\right.
$$

Šios priklausomybès koeficientas $\Omega(t)$ apskaičiuojamas pagal formulę:

$$
\Omega(t)=1+0,333\left[1-1,9^{-0,055\left(t-t_{0}-100\right)}\right] .
$$

Koeficientu $\Omega(t)$ ivertinamos ilgalaikès betono valkšnumo deformacijos, kai stebèjimo laikas $t$ kinta $100<t-t_{0}<\infty$ intervalu. Pagal normų [2] reikalavimus $\Omega(t)=\varphi_{l}(t)=1,34$, kai $t-t_{0} \rightarrow \infty$.

Remiantis (35) priklausomybe, grynojo valkšnumo charakteristika apskaičiuojama taip:

$$
\left\{\begin{array}{l}
\varphi^{*}\left(t, t_{0}\right)=\left[C_{a, 9}^{*}\left(t, t_{0}\right) k_{9}+\Delta\left(t_{0}\right) k_{6}\right] \times \\
\times E_{b}\left(t_{0}\right) \xi_{3}^{*} \xi_{4}, \text { esant } \mathrm{t}-\mathrm{t}_{0} \leq 100 \\
\varphi^{*}\left(t, t_{0}\right)=C^{*}\left(z+t_{0}, t_{0}\right) E_{b}\left(t_{0}\right) \Omega(t) \\
\text { esant } \mathrm{t}-\mathrm{t}_{0}>100, \mathrm{z}=\mathrm{t}-\mathrm{t}_{0}=100
\end{array}\right.
$$

Valkšnumo charakteristika, tenkinanti normų [1] nuostatas, apskaiciuojama pagal formulę:

$$
\varphi\left(t, t_{0}\right)=C\left(t, t_{0}\right) E_{b}\left(t_{0}\right)=\varphi^{*}\left(t, t_{0}\right)+\frac{E_{\left.b^{\left(t_{0}\right.}\right)}}{E_{b}(t)}-1 \text {. }
$$

Jeigu faktinis konstrukcijos apkrovimo laikas $t_{01}$ nesutampa su apskaičiuotu pagal (39) laiku $t_{0}$, tai išraiškose (35) ir (37) esantis betono apspaudimo laikas $t_{0}$ nustatomas priklausomai nuo betono stiprumo $R_{b p}$ apkrovimo metu pagal žinomą B. G. Skramtajevo formulę:

$$
\left\{\begin{array}{l}
t_{0}=10^{\frac{R_{b p}}{0,7 B}}, \text { kai } \mathrm{t}_{01}<60 \\
t_{0}=t_{01}, \text { kai } \mathrm{t}_{01} \geq 60
\end{array}\right.
$$

Pateikta grynojo valkšnumo mato (35) priklausomybẻ leidžia ilgalaikius procesus, skaiciuojant gelžbetonines konstrukcijas, ivvertinti valkšnumo teorijos metodais, tenkinant ir normų [2] apibrèžtos srities nuostatas. Armatüros išankstinio itempimo nuostoliai del betono valkšnumo, apskaičiuoti pagal $[10,15]$ metodiką ir taikant (35) priklausomybę, kai kuriais atvejais iki 10\% [16] skiriasi nuo nuostolių reikšmiu, nustatytų pagal normų [2] metodiką. 
(1, 28)

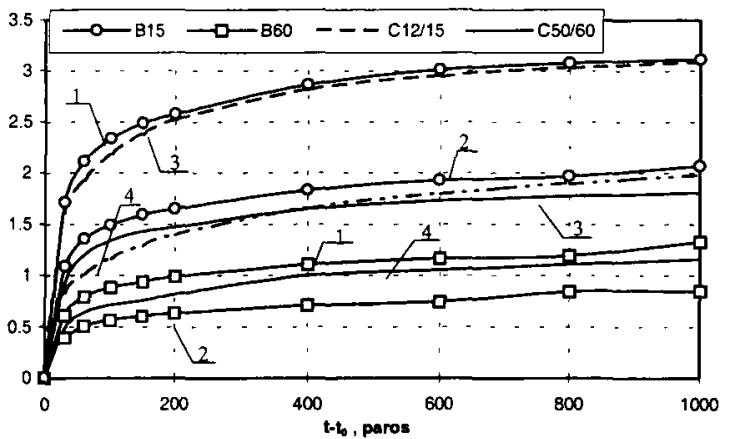

3 pav. Valkšnumo charakteristikos $\varphi\left(t, t_{0}\right)$, apskaičiuotos pagal (37-38) priklausomybes ir pagal normų EC-2 nuostatas: 1 - pagal (37-38), kai sąlyginis skerspjūvio matmuo $h=50 \mathrm{~mm}(r=2,5 \mathrm{~cm}), 2-$ kai $h=600 \mathrm{~mm}(r>20 \mathrm{~cm})$, 3 - pagal EC-2 [1], salyginis skerspjūvio matmuo $h=50$ $\mathrm{mm}, 4-\mathrm{EC}-2$ [1], $h=600 \mathrm{~mm}$

Fig 3. Creep coefficients $\varphi\left(t, t_{0}\right)$ calculated according to (37-38) relationships and according to the code EC-2 [1] regulations: 1 - by (37-38) when conventional cross-sectional dimension $h=50 \mathrm{~mm}(r=2.5 \mathrm{~cm}), 2$ - when $h=600$ $\mathrm{mm}(r>20 \mathrm{~cm}), 3-$ by EC-2 [1] with conventional dimension $h=50 \mathrm{~mm}, 4-\mathrm{EC}-2$ [1], with $h=600 \mathrm{~mm}$

Apskaičiuotu pagal (37-38) priklausomybes ir pagal normas EC-2 [1] valkšnumo charakteristikos $\varphi\left(t, t_{0}\right)$ palygintos 3 pav.

Kaip rodo 3 pav., grafikai, B15 gniuždymo klasès betono valkšnumo charakteristikos reikšmès, apskaiciuotos pagal (37-38) priklausomybes, yra 1,05-1,10 kartı didesnès už nustatytas pagal normas EC-2 [1], o B60 klasès betono - 1,25-1,34 karto mažesnès. Šis skirtumas atsiranda dél normy SNirT [2] ivertinamo nuostolių dèl betono valkšnumo mažesnio didèjimo per laiką. 1-2 pav. pateikti grafikai rodo, kad šios deformacijos, praejjus 100 parų po apkrovimo mažai skiriasi nuo deformaciju apskaičiuotu pagal NIIŽB-o [4] rekomendacijas ir normas EC-2 [1]. Ta pati tendencija pastebima lyginant ribiniu valkšnumo matų (kai $t \rightarrow \infty$ ) reikšmes (4 pav.).

Kaip rodo 4 pav. grafikai, normos [1] ir [6] panašiai ivertina tik vidutinių betono klasių ribinius valkšnumo matus. Priklausomai nuo mastelio faktoriaus aukštu betono klasių B50-60 ribinis valkšnumo matas, apskaičiuotas pagal normų EC-2 [1] metodiką, gali būti iki 1,23-1,47 karto didesnis už valkšnumo matą kurị reglamentuoja normos [6].

Ribinił valkšnumo matu reikšmés, apskaičiuotos pagal normu [2] nuostatas, remiantis (10) ir (35) priklausomybèmis, yra 0,96-1,40 karto mažesnès už normų [1] reglamentuojamą valkšnumo matą, kai sąlyginè skerspjūvio charakteristika $r=2,5 \mathrm{~cm}$ ir 1,15-1,60 karto mažesnès, kai $r 20 \mathrm{~cm}$ (4 pav.). Šių matų reikšmès, nustatytos pagal normų [2] nuostatas, ivertinant (10) ir (35) priklausomybes, yra 1,09-1,15 karto mažesnès už atitinkamas normụ [6] nustatytas reikšmes (4 pav.). Atsižvelgiant i normu [1, $2,6]$ reikalavimus, betono ribiniu valkšnumo matu reikšmès turi tenkinti ir šių normų ilgalaikių ilinkių skaičiavimo metodikos nuostatas.

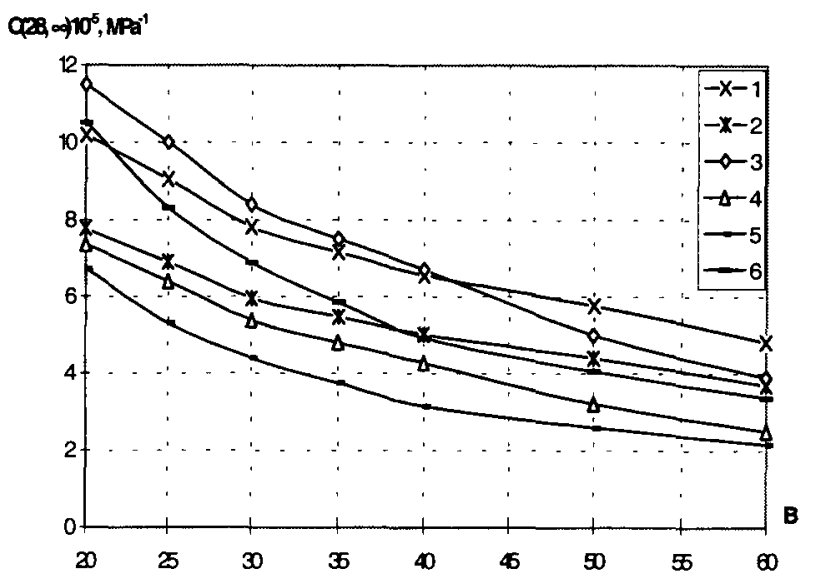

4 pav. Ribiniai valkšnumo matai $C(28, \infty)$, nustatyti pagal (10) ir (35) priklausomybes, normų EC-2 [1] ir normų [6] metodikas: 1 - pagal EC-2 [1], kai salyginis skerspjūvio matmuo $h=50 \mathrm{~mm}, 2$ - EC-2 [1], kai $h=600 \mathrm{~mm}, 3-$ pagal [6], kai salyginė skerspjūvio charakteristika $r=2,5 \mathrm{~cm}$, 4 - [6], kai $r>20 \mathrm{~cm}, 5$ - pagal (10) ir (35), kai $r>20 \mathrm{~cm}$, 6 - tas pats, kai $r=2,5 \mathrm{~cm}$

Fig 4. Limit values of specific concrete creep $C(28, \infty)$, calculated according to relationships (10) and (35), code EC-2 [1] and code [6] methods: 1 - according to EC-2 [1] when cross-sectional dimension $h=50 \mathrm{~mm}, 2-\mathrm{EC}-2$ [1], when $h=600 \mathrm{~mm}, 3$ - according to [6] when conventional cross-sectional characteristic $r=2.5 \mathrm{~cm}, 4-[6]$ when $r>20 \mathrm{~cm}, 5$ - according to (10) and (35) when $r>20 \mathrm{~cm}, 6$ - the same when $r=2.5 \mathrm{~cm}$

\section{Cementinès tešlos kiekio ir vandens cemento santy- kio įtaka betono valkšnumui}

Vienetinių valkšnumo rodiklių eksperimentinių tyrimų rezultatų analizè parodè, kad betono ilgalaikès deformacinès savybès priklauso ne tik nuo betono valkšnumą lemiančiu faktoriu aptartu 2-3 skyriuose, bet ir nuo kai kurių betono mišinio parametrų: vandens cemento santykio $\mathrm{v} / \mathrm{c}$ ir cementinès tešlos kiekio mišinyje $p_{c t}[14,17]$. Šiu faktorių normos nevertina. Priklausomai nuo etaloninio betono modelio šie faktoriai gali būti ivertinami koeficientais, pateiktais darbuose $[3,14]$.

Pasirinkus etaloninio betono modeli, tenkinanti LST 1330:1995 reikalavimus, cementinés tešlos kiekio itaka 
betono valkšnumui ivertinama koeficientu $\xi_{1}\left(p_{c t}\right)$, kuris gali būti apskaičiuotas pagal [14] pateiktą priklausomybę:

$$
\xi_{1}\left(p_{c t}\right)=5 p_{c t}
$$

Vandens cemento santykio įtakos betono valkšnumo deformacijoms ivertinančio koeficiento $\xi_{2}(v / c)$ išraiška, gauta matematiškai aprašant [3] pateiktus duomenis, kurie buvo modifikuoti pasirinktam etaloninio betono modeliui:

$$
\xi_{2}(v / c)=2,74(v / c)^{1,69}+0,12 .
$$

Cementinès tešlos kiekis $p_{c t}$ betono mišinyje taip pat gali būti apskaičiuotas pagal [14] formulę:

$$
p_{c t}=0,00042 v\left(1+\frac{c}{v}\right) \text {. }
$$

Žinant $1 \mathrm{~m}^{3}$ betono gamybai panaudoto vandens ir cemento kieki betono valkšnumo vienetiniai rodikliai, nustatyti pagal (35), (36) priklausomybes, dauginami iš koeficientu $\xi_{1}\left(p_{c t}\right)$ ir $\xi_{2}(v / c)$. Sie koeficientai apskaičiuojami pagal (40-42) formules.

\section{Tiesinio valkšnumo vienetinių rodiklių vertès paly- ginimas su eksperimentinių tyrimų rezultatais}

Statistiškai apdorojus daugelio eksperimentiniц betono vienetinių valkšnumo deformacijų tyrimų rezultatus, gauta etaloninio betono valkšnumo mato kreivè, kuri pateikta [3]. Šių ir apskaičiuotos pagal (35) priklausomybę, ivertinant (40-41) koeficientus, kreiviu grafikai pateikti 5 pav.

S. V. Kirejevos ir I. A. Rusinovo [18] atliktų eksperimentiniu betono valkšnumo mato tyrimų rezultatai palyginti su valkšnumo matu, apskaičiuotu pagal (35) priklausomybę, ivertinant (40-41) koeficientus (6 pav.).

Lyginant eksperimentiniu betono valkšnumo deformacijas su deformacijomis, nustatytomis pagal mūsų siūlomą metodiką ir normas [1], apskaičiuoti vidutiniai santykiai $\mathrm{\kappa}=C_{e k s p}\left(t, t_{0}\right) / C\left(t, t_{0}\right)$, ju vidutiniai kvadratiniai nuokrypiai $\sigma_{\kappa}$ bei variacijos koeficientai $\delta_{\kappa}$ (2 lent.). Toks statistinis vertinimas rodo visus teoriniu priklausomybiu nuokrypius nuo per laika $t$ atliktų valkšnumo deformaciju matavimų ir yra griežtesnis negu pateikiamas [12, 14], kur lyginami tik ribinių valkšnumo matų santykių statistiniai iverčiai.

Kaip rodo valkšnumo deformacijų teorinių ir eksperimentinių reikšmių statistinès analizès rezultatai, valkšnumo mato reikšmès, nustatytos pagal (35) formulę, ivertinant $(40-41)$ koeficientus, ir reikšmès, apskaičiuotos taikant normų EC-2 metodiką [1], vidutiniškai vienodai ( $\kappa=0,89$ karto) skiriasi nuo eksperimentinių tyrimy rezultatú. Palyginus teorinių valkšnumo matụ variaciją su eksperimentiškai nustatytais rezultatais, gauta, kad mūsu siūloma valkšnumo vienetinių rodiklių nustatymo metodika geriau aprašo eksperimentinių tyrimų rezultatus (variacijos koeficientas $\delta_{\kappa}=27,7 \%$ ), negu normos EC-2 [1] (variacijos koeficientas $\delta_{\mathrm{x}}=31,9 \%$ ). Be to, pasiūlyta metodika leidžia ivertinti ir faktinių betono mišinio parametrų įtaką betono deformatyvumui.

a)

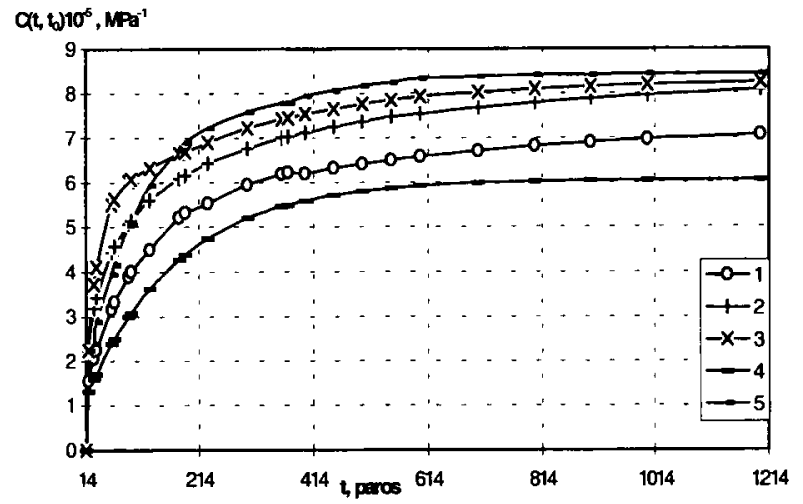

b)

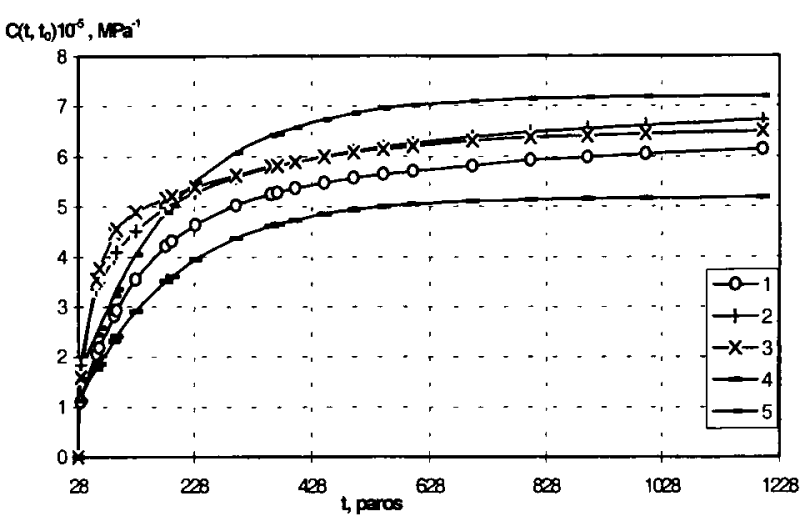

5 pav. Valkšnumo matu kitimą vaizduojantys grafikai, kai apkrovimo laikas $t_{0}=14$ paru (a) ir $t_{0}=28$ paros (b): etaloninio betono pagal [3] - 1, pagal normas [1] - 2, pagal (35), ivertinant (40) ir (41) formules - 3, pagal NIIŽB-o rekomendacijų [4] metodika, esant minimaliam betono mišinio slankumui -4 , tas pats, esant maksimaliam slankumui -5

Fig 5. Diagrams representing variation of specific creep when load is applied at $t_{0}=14$ days (a) ir $t_{0}=28$ days (b): standard concrete according to [3]-1, according to the code [1] -2 , according to (35) with consideration of formulas (40) and (41) -3 , according to the method recommended by NIIZHB [4] for the minimum concrete mixture slump value -4 , the same for the maximum slump value -5 


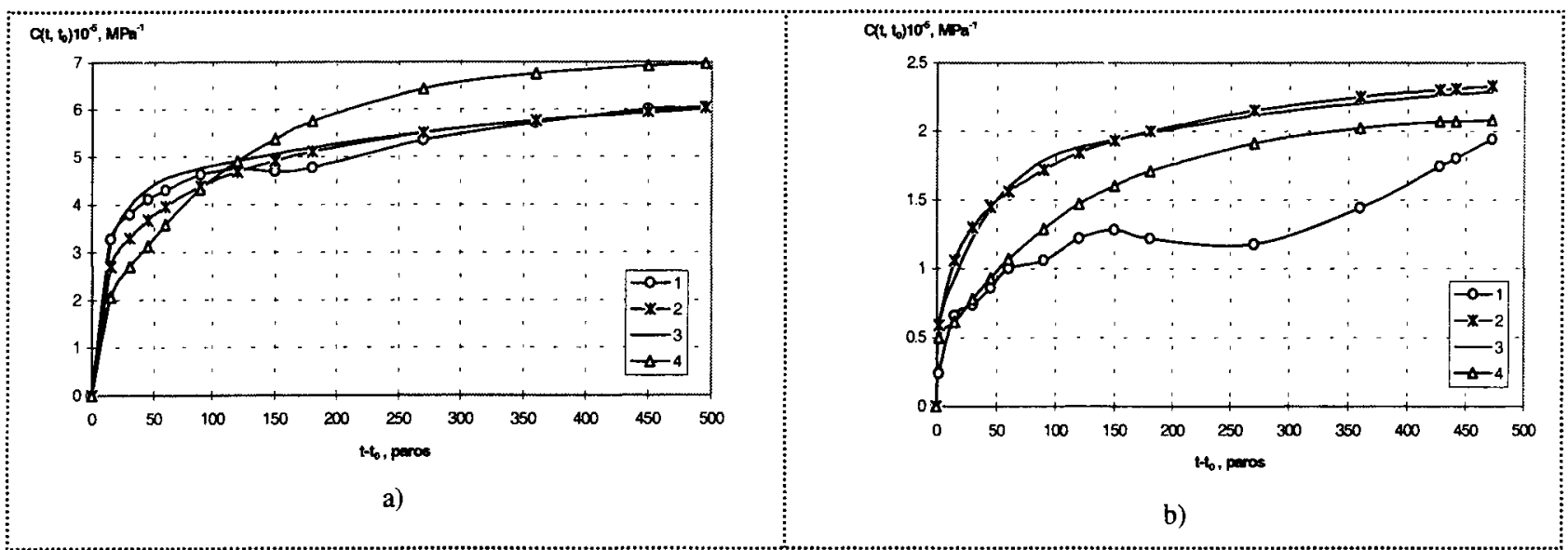

6 pav. Valkšnumo matai pagal S. V. Kirejevos ir I. A. Rusinovo [18] eksperimentinių tyrimu rezultatus - 1, pagal normas [1] - 2, pagal (35) priklausomybę, ivertinant (40) ir (41) formules - 3, pagal NIIŽB-o rekomendacijas [4] - 4. Apkrovimo laikas: a) $t_{0}=7$ paros (I - serija), b) $t_{0}=384$ paros (IVe - serija)

Fig 6. Specific creep values according to the test results of S. V. Kirejeva and I. A. Rusinov [18] - 1, according to the code [1] -2 , according to relationship (35) with allowance for formulas (40) and (41) -3 , according to the recommendations of NIIZHB [4]. Load application time: a) $t_{0}=7$ days (series - I), b) $t_{0}=384$ days (series - IVe)

2 lentelè. Eksperimentinių valkšnumo matų reikšmių ir apskaičiuotų pagal (35) ivertinus (40-41) priklausomybes ir normas [1] statistinés analizès rezultatai

Table 2. Results of statistical analysis of experimental values of specific creep and these values calculated according to (35) with consideration of $(40-41)$ relationships and according to the code [2]

\begin{tabular}{|c|c|c|c|c|c|c|c|c|c|c|}
\hline \multirow[t]{2}{*}{$\begin{array}{c}\text { Eksperimentiniu tyrimu } \\
\text { autorius }\end{array}$} & \multirow[t]{2}{*}{$\begin{array}{l}\text { Prizmiu } \\
\text { skaiżius }\end{array}$} & \multirow[t]{2}{*}{$\begin{array}{c}t_{0}, \text { pa- } \\
\text { ros }\end{array}$} & \multirow[t]{2}{*}{$\begin{array}{c}t, \\
\text { paros }\end{array}$} & \multirow[t]{2}{*}{$\begin{array}{l}\text { Imties } \\
\text { dydis }\end{array}$} & \multicolumn{3}{|c|}{$\begin{array}{c}\text { Pagal (35), ivertinus } \\
(40-41)\end{array}$} & \multicolumn{3}{|c|}{$\begin{array}{c}\text { Pagal normy EC-2 [1] } \\
\text { metodika }\end{array}$} \\
\hline & & & & & $k_{c}$ & $\sigma_{\mathrm{x}}$ & $\delta_{\mathrm{k}}$ & $\mathbf{K}_{c}$ & $\sigma_{\mathrm{x}}$ & $\delta_{\mathrm{k}}$ \\
\hline \multirow{7}{*}{$\begin{array}{c}\text { Etaloninis betonas } \\
\text { pagal [3] }\end{array}$} & & 7 & 1200 & 25 & 0,656 & 0,045 & 0,068 & 0,744 & 0,044 & 0,060 \\
\hline & & 14 & 1200 & 23 & 0,722 & 0,139 & 0,193 & 0,821 & 0,077 & 0,094 \\
\hline & & 28 & 1200 & 22 & 0,832 & 0,123 & 0,148 & 0,839 & 0,108 & 0,128 \\
\hline & & 60 & 1200 & 23 & 0,796 & 0,144 & 0,181 & 0,742 & 0,127 & 0,172 \\
\hline & & 90 & 1200 & 18 & 0,791 & 0,139 & 0,176 & 0,748 & 0,121 & 0,162 \\
\hline & & 180 & 1200 & 18 & 0,795 & 0,142 & 0,166 & 0,751 & 0,132 & 0,160 \\
\hline & & 360 & 1200 & 11 & 0,745 & 0,157 & 0,211 & 0,749 & 0,155 & 0,207 \\
\hline \multirow{4}{*}{ A. D. Ross [5] } & & 8 & 200 & 18 & 0,949 & 0,067 & 0,071 & 0,952 & 0,091 & 0,10 \\
\hline & & 28 & 200 & 14 & 1,108 & 0,059 & 0,053 & 1,185 & 0,120 & 0,101 \\
\hline & & 60 & 200 & 10 & 1,129 & 0,136 & 0,121 & 1,192 & 0,114 & 0,096 \\
\hline & & 90 & 200 & 6 & 1,238 & 0,134 & 0,108 & 1,05 & 0,20 & 0,191 \\
\hline \multirow{3}{*}{ N. I. Katinas [19] } & & 28 & 128 & 9 & 0,807 & 0,094 & 0,116 & 0,587 & 0,071 & 0,121 \\
\hline & & 140 & 300 & 10 & 0,742 & 0,168 & 0,226 & 0,506 & 0,124 & 0,247 \\
\hline & & 50 & 190 & 10 & 0,634 & 0,054 & 0,075 & 0,463 & 0,047 & 0,103 \\
\hline \multirow{6}{*}{$\begin{array}{l}\text { S. V. Kirejeva, } \\
\text { I. A. Rusinovas } \\
\text { I - serija [18] }\end{array}$} & 3 & 7 & 502 & 12 & 0,971 & 0,036 & 0,035 & 1,04 & 0,081 & 0,078 \\
\hline & 3 & 18 & 1023 & 20 & 0,887 & 0,111 & 0,125 & 1,015 & 0,092 & 0,090 \\
\hline & 3 & 30 & 1125 & 20 & 1,053 & 0,146 & 0,139 & 1,079 & 0,119 & 0,110 \\
\hline & 3 & 60 & 1155 & 20 & 1,129 & 0,247 & 0,219 & 1,113 & 0,217 & 0,195 \\
\hline & 3 & 90 & 1185 & 20 & 1,248 & 0,331 & 0,267 & 1,232 & 0,308 & 0,249 \\
\hline & 3 & 383 & 1478 & 20 & 1,243 & 0,204 & 0,164 & 1,525 & 0,247 & 0,162 \\
\hline \multirow{5}{*}{$\begin{array}{l}\text { S. V. Kirejeva, } \\
\text { I. A. Rusinovas } \\
\text { IVe-serija [18] }\end{array}$} & 3 & 15 & 456 & 13 & 0,679 & 0,063 & 0,092 & 0,715 & 0,087 & 0,122 \\
\hline & 3 & 29 & 456 & 13 & 0,970 & 0,124 & 0,128 & 0,888 & 0,139 & 0,157 \\
\hline & 3 & 60 & 696 & 17 & 0,616 & 0,075 & 0,121 & 0,623 & 0,082 & 0,132 \\
\hline & 3 & 90 & 696 & 17 & 0,601 & 0,098 & 0,163 & 0,523 & 0,082 & 0,158 \\
\hline & 3 & 383 & 856 & 14 & 0,649 & 0,106 & 0,163 & 0,631 & 0,100 & 0,158 \\
\hline \multirow{3}{*}{$\begin{array}{c}\text { O. J. Bergas, } \\
\text { A. I. Roškovas [20] }\end{array}$} & & 3 & 253 & 10 & 0,964 & 0,062 & 0,064 & 0,912 & 0,038 & 0,049 \\
\hline & & 28 & 278 & 10 & 0,968 & 0,084 & 0,087 & 0,789 & 0,083 & 0,104 \\
\hline & & 90 & 340 & 10 & 0,911 & 0,049 & 0,054 & 0,969 & 0,056 & 0,057 \\
\hline \multicolumn{4}{|c|}{ Bendras pagal visus eksperimentus } & 433 & 0,881 & 0,244 & 0,277 & 0,886 & 0,283 & 0,319 \\
\hline
\end{tabular}




\section{Išvados ir rekomendacijos}

1. Atlikta galiojančiu normy SNirT [2] armatūros itempimo nuostolių dèl betono valkšnumo skaičiavimo metodikos analizè, pasiūlytos B15-B60 klasių betonцุ tiesinio valkšnumo mato priklausomybès, tenkinančios praktinių skaičiavimų tikslumą normų [2] nuostatų srityje.

2. Pasiūlytos valkšnumo mato priklausomybès ivertina svarbiausius valkšnumo deformacijas lemiančius faktorius: betono klasę, apkrovimo ir stebejimo laikus, masteli ir aplinkos drègmę bei cemento ir cementinès tešlos kieki.

3. Nustatyta, kad teorinès valkšnumo matų reikšmès, apskaičiuotos pagal pasiūlytą metodika, geriau sutampa (variacijos koeficientas $\delta_{\kappa}=27,7 \%$ ) su pateiktų eksperimentiniu tyrimu rezultatais, negu normos EC-2 [1] (variacijos koeficientas $\delta_{\mathrm{k}}=31,9 \%$ ).

4. Pasiūlytos valkšnumo vienetinių charakteristikų priklausomybès ir betono rodikliu kaitos ivertinimo metodika gali būti taikoma ilgalaikių apkrovų veikiamų gelžbetoninių konstrukcijų skaičiavimams.

\section{Literatũra}

1. ENV 1992-1-1. Eurocode 2: Design of concrete structures - Part 1: General rules and rules for buildings, 1991. $114 \mathrm{p}$.

2. СНиП 2.03.01-84*. Бетонные и железобетонные конструкции. М.: Госстрой СССР. $1989.80 \mathrm{c}$.

3. И. Е. Прокопович, В. А. Зедгенидзе. Прикладная теория ползучести. М.: Стройиздат, 1980. 240 с.

4. Рекомендации по учету ползучести и усадки бетона при расчете бетонньх и железобетонных конструкций. М.: НИИЖБ Госстроя СССР. 1988. $122 \mathrm{c}$.

5. С. В. Александровский. Расчет бетонных и железобетонных конструкций на изменения температуры и влажности с учетом ползучести. М.: Стройиздат, 1973. $432 \mathrm{c}$.

6. СНиП 2.05.01-84. Мосты и трубы. М.: Госстрой СССР, 1988. $199 \mathrm{c}$

7. Н. Х. Арутюнян, А. А. Зевин. Расчет строительньгх конструкций с учетом ползучести. М.: Стройиздат, 1988. $256 \mathrm{c}$

8. Г. В. Марчюкайтис, Е. Ю. Дулинскас. Напряженнодеформированное состояние преднапряженных железобетонньгх конструкций при теплообработке. Вильнюс, 1975. $122 \mathrm{c}$

9. Beton - Kalender 1993. Taschenbuch für Beton - Stalbeton - und Spannbetonbau sowie die verwandten Facher. Teil II. Schriftleitung o. Professor Dr. -Ing. J. Eibl Karlsrue. Verlag für Architektur und technische Wissenschaften. Berlin: Emst \& Sohn. 1993. 815 S.

10. E. Dulinskas, R. Balevičius. Armatūros išankstinio itempimo nuostoliu dèl betono valkšnumo skaičiavimo ypatumai, taikant galiojančiu Lietuvoje ir Euronormy nuostatas // VI tarp. konf. „Naujos statybines medžiagos, konstrukcijos ir technologijos“, ivykusios Vilniuje 1999 m. gegužès 19-22 d., straipsniai. III tomas. V.: Technika, 1999, p. 121-126.

11. Е. Н. Львовский. Статистическое моделирование деформаций ползучести бетона на ЭВМ // Бетон и железобетон, № 11. М.: Издательство литературы по строительству, 1992, с. 18-19.

12. Е. Н. Щербаков. Физические и феноменологические основы прогнозирования механических свойств бетона для расчетов железобетонных конструкций // Автореферат дис... доктора технических наук. М.: ВЗИСИ, 1987, $49 \mathrm{c}$.

13. Z. P. Bažant, Y. - P. Xi, S. Baveja, I. Carol. Preliminary guidelines and recommendation for characterising creep and shrinkage in structural design codes // Creep and shrinkage of concrete. Proceedings of the fifth international RILEM symposium. Barcelona, Spain, September 6-9, 1993, p. 805-829.

14. Е. Н. Щербаков. О прогнозе величин деформаций ползучести и усадки тяжелого бетона в стадии проектирования конструкций // Исследование деформаций, прочности и долговечности бетона транспортньг сооружений. Труды ВНИИТС. Вып. 70. М.: Транспорт, 1969 , c. 39-84.

15. E. Dulinskas, R. Balevičius, L. Kairyte. Itemptojo gelžbetonio centriškai armuotụ elementų betono ilgalaikių netampriu deformaciju ir fiziniu mechaniniu rodikliu kitimo ivertinimas // Statyba ir architektüra: Konferencijos medžiaga. Kaunas, 1998, p. 145-152.

16. E. Dulinskas, R. Balevičius, L. Kairytè. Gelžbetoniniu konstrukcijų betono netampriu deformacijų ir fiziniu mechaniniu rodikliu kitimo ivertinimas // V tarp. konf. „Naujos statybinès medžiagos, konstrukcijos ir technologijos“, ivykusios Vilniuje $1997 \mathrm{~m}$. gegužès 21-24 d., straipsniai. III tomas. V.: Technika, 1997, p. 45-56.

17. И. Н. Ахвердов. Основы физики бетона. М.: Стройиздат, $1981.463 \mathrm{c}$

18. С. В. Киреева, И. А. Русинов. Влияние возраста бетона в момент загружения на его ползучесть. Киев: Госстройиздат УССР, $1970.64 \mathrm{c}$.

19. Н. И. Катин. Иследование ползучести бетона при высоких напряжениях // Исследование свойств бетона и железобетонных конструкций. Труды ВНИИЖБ. Вып. 4. М.: Госстройиздат, 1959, с. 74-153.

20. О. Я. Берг, А. И. Рожков. Исследование неупругих деформаций и структурных изменений высокопрочного бетона при длительном действии сжимающих напряжений // Исследование деформаций, прочности и долговечности бетона транспортных сооружений. Труды ВНИИТС. Вып. 70. М.: Транспорт, 1969, с. 3-38.

Iteikta 20000229

\section{DETERMINATION OF UNIT CHARACTERISTICS OF CONCRETE LINEAR CREEP}

\section{R. Balevičius, E. Dulinskas}

S u m m a r y

It is very important to take into account time-dependent non-elastic deformations and variation of concrete mechanical characteristics in analysis of concrete structures. In codes of many countries, such as ENV 1992-1-1 (Eurocode) [1], ACI 209-92 (USA), AS 3600-1988 (Australia), DIN 4227 (Germa- 
ny) and others, variation of creep deformations and physical mechanical characteristics with time is specified. The Code acting in Lithuania SNiT (Russ. CHиП 2.03.01-84*) [2] does not describe these characteristics directly.

Calculation of time-dependent processes in the code acting in Lithuania SNiT [2] is associated with specific creep characteristics (specific creep, coefficient of creep) and with regulation of creep deformations. Such integral characteristics as steel prestress losses due to concrete creep associated with these specific characteristics are determined by empirical formulas which are obtained by tests with verification of stress and strain state of individual members.

There are many investigations for determination of concrete creep characteristics. In the investigation [3], different relationships for determining specific characteristics of ,young", and ,old" concrete are proposed to apply, in recommendations [4] characteristics are presented according to their authors only for design, relationships presented in monograph [5] describe very well the creep of "young"' concrete, code [6] regulates only limit values of creep characteristics. Characteristics determined by Eurocode [1] depend on the main factors influencing creep deformations but their relationship with regulations of the code [2] used in Lithuania is not clear.

Therefore in this investigation relationships of specific creep characteristics for various compression grades of normal weight concrete describing great area of long-term deformations and taking into account the main factors influencing concrete creep were proposed. The proposed relationships also comply with regulation area of the code [2]

Analysis of specific concrete creep deformations based on steel prestress loss due to concrete creep calculation method [2] is presented in Chapter 2. Relationships for pure concrete specific creep (20-21) and for creep coefficient (23) were obtained. Comparison of these expressions with specific creep calculated according to code EC-2 [1] and recommended in [4] methods is shown in Figs 1-2.

In Chapter 3, mathematical description of pure specific concrete creep (21) and of pure creep coefficient (23) based on theory of elastic plastic body is presented. Comparison of specific concrete creep characteristics determined by (35) and (37) relationships with analogous characteristics applied in codes [1, $4]$ is shown in Figs 3-4.

In Chapter 4-5, coefficients (40), (41) evaluating the influence of water-cement ratio and quantity of cement paste on concrete creep deformations are presented. Analysis of experimental results of investigations of specific creep characteristics shows that time-dependent deformation properties depend not only on factors by which concrete creep is specified in codes and discussed in Chapters $3-4$, but also on quantity of cement paste and water-cement ratio. Conformity of specific creep values determined by relationships (35) proposed by us taking into account coefficients (40-41) with standard concrete [3] and experimental creep investigation results [18] are shown in Figs 4-5. Statistical analysis of experimental and theoretical concrete creep deformation values determined according to the method proposed by us and by the code [1] is presented in Table 2. Mean ratios $\mathrm{K}=C_{\text {eksp }}\left(t, t_{0}\right) / C\left(t, t_{0}\right)$, mean square

deviations $\sigma_{\kappa}$ and coefficient of variation $\delta_{\kappa}$ were calculated. It was determined that theoretical values of specific creep calculated by the proposed method comply better (coefficient of variation $\delta_{\mathrm{K}}=27.7 \%$ ) with presented test results than code EC-2 [1] (coefficient of variation $\delta_{\mathrm{k}}=31.9 \%$ ) (Table 2).

Analysis of method of calculation of steel prestress loss due to concrete creep according to the acting code SNiT [2] was made and relationships for linear specific creep of concrete B15 - B60 grade were proposed to satisfy the accuracy of practical calculations in the area of regulations of the code [2]. Specific creep relationships presented take into account the most important factors effecting creep deformations: concrete grade, times of loading and observation, scale and ambient humidity, quantity of cement and cement paste. These relationships of specific creep characteristics and the method of evaluation of variation of concrete characteristics can be applied for analysis of concrete structures under the action of long-term loads.

Robertas BALEVIČIUS. PhD student. Dept of Reinforced Concrete and Masonry Structures. Vilnius Gediminas Technical University (VGTU), Sauletekio al. 11, LT-2040 Vilnius, Lithuania.

MSc (1996). Co-author of 5 scientific articles. Research interests: evaluations of time-dependent non-elastic concrete deformations in concrete structures.

Eugedijus DULINSKAS. Doctor, Assoc Professor. Dept of Reinforced Concrete and Masonry Structures. Director of Research Laboratory of Buildings, Structures and Materials. Vilnius Gediminas Technical University (VGTU), Sauletekio al. 11, LT-2040 Vilnius, Lithuania

Doctor (1974, engineering sciences), Assoc Professor (1980). In 1986-1990 joint research of concrete structures and probations in Germany. Author of 81 articles and 5 monographs. Research interests: mechanics of concrete, concrete and masonry structures, timedependent actions, construction work in railway transport, renovation and strengthening of buildings and construction work. 